\title{
Penerapan Konsep Tri Hta Karana Di Daya Tarik Wisata Danau Beratan
}

Yanuaris F. Lagut a, 1, Ida Bagus Suryawan a, 2

1gaulodaat@gmail.com, 2idabagussuryawan@unud.ac.id

a Program Studi S1 Destinasi Pariwisata, Fakultas Pariwisata,Universitas Udayana, Jl. Dr. R. Goris, Denpasar, Bali 80232 Indonesia

\section{Abstract}

The Development of the Tri Hita Karana concept start begins the study results by Pusat Kajian Bali in 2000. This study involved the local communities, scientists and various observers of development. This study resulted in a lot of concepts about the development of Tri Hita Karana which require development in Bali based on the concept. Tri Hita Karana concept is the basic for the implementation or benchmarks in sustainable tourism development in Bali. Beratan Lake is one of the many examples of tourist attraction that based on the concept of Tri Hita Karana. Researchers used the Tri Hita Karana Award and Accreditation in 2014 as a reference to provide an assessment of the existence of the Beratan Lake.

The results of this study showed that the condition of the Beratan Lake at the stage of development belonging to very good.

\section{PENDAHULUAN}

Pembangunan akomodasi wisata di Bali selama ini membawa dampak yang besar terhadap kondisi dan keberlanjutan kebudayaan Bali. Pembangunan seharusnya dibuat mengacu pada konsep yang sudah lama berlaku di Bali yaitu Tri Hita Karana. Tri Hita Karana memiliki arti tiga penyebab kebaikan, kesejahteraan atau kebahagiaan, yang bersumber dari tiga hubungan yang harmonis, antara manusia dengan Tuhan Yang Maha Esa, antar sesama manusia dan antar manusia dengan alam serta makhluk hidup lainnya (Dalem, 2007). Pengertian Tri Hita Karana memberikan arti penting bagi kehidupan manusia jika setiap pribadi mampu mengamalkan konsep tersebut.

Konsep Tri Hita Karana juga harus diterapkan di dalam pembangunan sebuah akomodasi. Pembangunan yang dimaksud berupa penetapan tata ruang yang digunakan yaitu tata letak tempat suci dengan tempat aktifitas manusia, dan keberadaan alam disekitarnya. Konsep Tri Hita Karana mempunyai tiga bagian yaitu Parhyangan, Pawongan dan Palemahan. Pada tahun 2000 diadakan seminar internasional yang digelar oleh Pusat Kajian Bali (Pusaka Bali) mengkaji tentang Tri Hita Karana dengan melibatkan masyarakat, tokoh, ilmuwan serta pengamat pembangunan dan kegiatan ini berhasil mendapatkan lebih dari 40 makalah terkait konsep, butir-butir pemikiran serta teknik implementasi Tri Hita Karana.

Hasil dari pertemuan tersebut merupakan bank data awal yang digunakan dalam mendukung penetapan kriteria lomba, sertifikasi pariwisata dari Bali dengan nilai-nilai Tri Hita Karana dalam Tri Hita Karana Tourism Award and Accreditation (Dalem, 2007). Mengacu pada hal tersebut dilakukan penilaian kepada lingkungan kawasan daya tarik wisata danau Beratan, Bedugul sehingga bisa menjawab indikator yang terdapat dalam Tri Hita Karana Tourism Award and Accreditation 2014. 


\section{Metode}

Lokasi penelitian di lakukan pada areal daya tarik wisata Danau Beratan, Bedugul. Metode yang dilakukan pada penelitian ini yaitu melakukan observasi ke lokasi yang diteliti, kemudian mengisi keterangan pada buku panduan Tri Hita Karana Award dan Accreditation 2014. Dalam buku panduan tersebut terdapat kriteria-kriteria ideal untuk memenuhi syarat Tri Hita Karana. Hasil itu akan dijumlahkan skor akhir untuk mengetahui tingkatan kualitas mutu daya tarik wisata Danau Beratan, Bedugul.

\section{Pembahasan}

Penilaian yang dilakukan pada penelitian ini menggunakan klasifikasi seperti tabel 1.1 berikut:

\begin{tabular}{|c|c|c|l|}
\hline No. & Nilai & Mutu & \multicolumn{1}{|c|}{ Keterangan } \\
\hline 1 & $85-$ & A & $\begin{array}{l}\text { Istimewa/excellent } \\
\text { sertifikat dan trophy emas }\end{array}$ \\
\hline 2 & $75-84$ & B & $\begin{array}{l}\text { Baik/good : sertifikat dan } \\
\text { trophy perak }\end{array}$ \\
\hline 3 & $65-74$ & $\mathrm{C}$ & $\begin{array}{l}\text { Cukup/credit :sertifikat dan } \\
\text { trophy perunggu }\end{array}$ \\
\hline 4 & $0-64$ & - & $\begin{array}{l}\text { Afiliasi (Affiliations) : perlu } \\
\text { pembinaan }\end{array}$ \\
\hline
\end{tabular}

(sumber: THK Award and Accreditation)

Penilaian ini berdasarkan bagian dari salah satu unsur THK yaitu Palemahan. Palemahan berasal dari kata lemah yang memiliki arti tanah, tanah pekarangan/wilayah pemukiman (Yasa dan Yuhaeni, 2000 dalam
Dalem, 2007:87). Palemahan termaksud dalam pengisisan nilai THK Award and Accreditation 2014 adalah posisi bangunan di lingkungan sekitar seperti tempat suci, tempat kegiatan manusia dan taman. Posisi bangunan ini berlandaskan konsep Tri Mandala. Tri Mandala yaitu ungkapan tiga tata nilai wilayah ruang yakni: ruang sakral/spiritual-ruang profan/komunal-ruang pelayanan/komersial. Struktur Tri Mandala mengacu pada orientasi gunung-laut dan orientasi terbit-terbenam matahari. Pedoman gunung-laut pada orientasi ini, tata ruang hulu digunakan sebagai kegiatan spiritual, disebut "Utama Mandala". Ruang komunal berada di tengah, disebut "Madya Mandala". Ruang pelayanan diposisikan pada bagian hilir, disebut "Nista Mandala". Konsep Tri Hita Karana dalam proses penilaian harus dijawab pada kuesioner Tri Hita Karana Award and Accreditation 2014. Pada kuesioner itu terdapat lima point penilaian dari setiap pertanyaan yang harus terjawab. Nilai point tersebut berurutan mulai dari no 5,4,3,2,1 dan peneliti memberikan penilaian terhadap bangunan tersebut. Hasil dari penilaian tersebut kemudian diberikan catatan/ keterangan alasan memberikan penilaian. Berikut ini akan dijabarkan hasil pemberian penilaian dan catatan terhadap masing-masing bidang penilaian.

1. Indikator Penilaian: idealnya bangunan mampu menangani sampah dengan baik dan mengurangi produksi sampah yang dibuang ke 
lingkungan. Tolok Ukur Penilaian No 2: sebagian sampah organik dimanfaatkan, dan sampah lainya dibuang ke TPA atau dikelola pihak lain. Catatan: Di Danau Beratan terdapat tempat sampah yang digunakan untuk menampung sampah. sampah organik dan nonorganic disimpan pada tempat sampah yang berbeda

2. Indikator penilaian: Idealnya bangunan punya zonasi sesuai dengan konsep tradisional tri mandala. Tolok ukur: Penilaian No. 5 zonasi lengkap. Tempat suci pelinggih di utama mandala terpisah dengan zona lainya dan dibatasi tembok penyengker. Catatan: Di salah satu sudut Danau Beratan/disamping kanttin terdapat padmasana yang sudah dibatasi dengan tembok untuk memisahkannya dengan bangunan lainya.

3. Indikator Penilaian: idealnya bangunan menyiapkan lahan dengan proporsi yang sesuai dengan konsep sanga mandala. Tolok Ukur: Penilaian No. 5 Proposional (utama mandala $1 / 9$, madya mandala5/9, nista mandala $3 / 9$ ). Catatan: Hasil pengamatan untuk penggunaan lahan sudah sesuai proporsi masing-masing. Ini terlihat dari adanya utama mandala, madya mandala dan nista mandala.

4. Indikator penilaian: idealnya bangunan mampu menangani sampah dengan baik dan mengurangi produksi sampah yang dibuang ke lingkungan. Tolok Ukur: Penilaian No 2 sebagian sampah organik dimanfaatkan, dan sampah lainya dibuang ke TPA atau dikelola pihak lain. Catatan: Di Danau Beratan terdapat tempat sampah yang digunakan untuk menampung sampah. sampah organik dan nonorganic disimpan pada tempat sampah yang berbeda

5. Indikator: Idealnya bangunan punya zonasi sesuai dengan konsep tradisional tri mandala. Tolok ukur: Penilaian No. 5 zonasi lengkap. Tempat suci pelinggih di utama mandala terpisah dengan zona lainya dan dibatasi tembok penyengker. Catatan: Di salah satu sudut Danau Beratan terdapat padmasana yang sudah dibatasi dengan tembok untuk memisahkannya dengan bangunan lainya.

6. Indikator: idealnya bangunan menyiapkan lahan dengan proporsi yang sesuai dengan konsep sanga mandala. Tolok ukur: Penilaian No. 5 Proposional (utama mandala 1/9, madya mandala5/9, nista mandala 3/9). Catatan: Hasil pengamatan untuk penggunaan lahan sudah sesuai proporsi masing-masing. Ini terlihat dari adanya utama mandala, madya mandala dan nista mandala.

7. Indikator: idealnya bangunan memiliki struktur sesuai dengan konsep tri angga. Tolok ukur: Penilaian No 5. semua fasilitas dan sarana yang dimiliki bangunan mengikuti konsep tri angga. Catatan: gedung yang berada di Danau Beratan semuanya memiliki kepala: atap limas, badan: gedung, kaki: bataran/fondasi bawah lantai

8. Indicator: idealnya bangunan punya IPAL/STP dan berfungsi dengan baik. Tolok ukur: Penilaian No. 2 punya septic tank berseri IPAL sederhana, tidak ditest secara rutin dan/atau hasil test memenuhi syarat 1-30\%. Catatan: Mempunyai septic tank berseri, tidak dilakukan secara rutin, karena sampai saat ini belum pernah terjadi hambatan saluran septic tank. 
9. Indikator: idealnya bangunan punya program peyelamatan dan pelestarian lingkungan. Tolok ukur: Penilaian No. 4 Memiliki program yang baik dan berpartisipasi aktif secara periodik tetapi tanpa menerapkan evaluasi dan penyempurnaan pelaksanaan program. Catatan: Setiap hari jumat diadakan kegiatan pembersihan lingkungan secara rutin. Di awal bulan diadakan aksi bersih dilingkungan bersama.

10. Indikator: idealnya bangunan memanfaatkan lahan secara efisien dan melakukan konservasi lahan dengan baik. Tolok ukur: Penilaian. No 5. Catatan: Lahan yang tersedia digunakan dengan efektif untuk keberadaan bangunan.

Kondisi lahan yang cukup sempit menjadikan jarak antar banguan cukup dekat juga.

11. Indikator: idealnya bangunan tidak memiliki konflik terkait dengan bidang lingkungan. Tolok ukur: Penilaian No. 1 sering terjadi konflik (>3kali). Catatan: Hasil wawancara dengan bapak I Wayan Suardana, sering terjadi perebutan lahan parkir dengan pihak, karena menggunakan tempat parkir di areal lingkungan sekitar.

12. Indicator: idealnya lingkungan bangunan punya keanekaragaman flora yang tinggi. Tolok ukur: Penilaian No 5. Catatan: Memiliki berbagai macam jenis tumbuh-tumbuhan, yang dirawat dengan baik pula.

13. Indikator: idealnya bangunan melestarikan tanaman langka /dilindungi. Tolok ukur: Penilaian No. 1 sangat sedikit (maks. 1 jenis tanaman langka/ dilindungi per 1 ha). Catatan: Kampus hanya memiliki 1 jenis tanaman langka yaitu simbrah, namun terdapat di beberapa titik.

14. Indikator: idealnya, bangunan punya taman yang mencerminkan unsur-unsurpanca mahabuta. Tolok ukur: Penilaian No. 5 Ada unsur apah (kolam, air gemericik), teja (lampu, penyinaran, penerangan, sinar matahari), pertiwi (tanah/pekerasan/batu, termasuk patung), akasa (zat ether, atmosfir, dll), bayu (angin, sirkulasi udara, suara alam dll). Catatan: Danau Beratan memiliki taman - taman kecil yang terdapat di bagian depan masing-masing gedung dan sudah mencermirkan unsur-unsur panca mahabuta yang lengkap, terdapat dua kolam ikan, 1 di dekat padmasana.

15. Indikator: Idealnya, bangunan irit memakai air. Tolok ukur: Penilaian No. 5 Pemakaian air maksimal 50 liter/ orang per hari. Catatan: Penggunaan air sesuai dengan jumlah debit air yang terdapat di Danau Beratan.

16. Indikator: Idealnya, bangunan efisien memanfaatkan energy. Tolok ukur: Penilaian No. 1 Tidak memakai proses (pengaturan menyalakan dan mematikan listrik, himbauan untuk hemat energy) dan alat hemat energy (memakai bola lampu hemat energy, sumber energy matahari atau solar cell, dll). Catatan: Hasil pengamatan: Untuk penggunaan listrik di kawasan daya tarik, tidak terdapat batasan penggunaan tenaga listrik dari PLN terhadap penerangan.

17. Indikator: Idealnya, bangunan punya (dan menerapkan) Sistem Manajemen Lingkungan. Tolok ukur: Penilaian No. 1 Tidak memiliki Sistem Manajemen Lingkungan. Catatan: Tidak 
terlihat penerapan dan pelaksanaan manajemen lingkungan.

18. Indicator: Idealnya, bangunan memanfaatkan $100 \%$ cleaning chemical yang biodegradable. Tolok ukur: PenilaianNo. 1 Menggunakan bahan kimia (cleaning chemical) yang biodegradable dibawah 25\%. Catatan: Penggunaan pembersih lantai maupun ruangan yang tidak ramah lingkungan seperti superpel, wipol, sos.

19. Indikator: idealnya, bangunan mampu menangani B3 (bahan berbahaya racun) dengan baik. Tolok ukur: Penilaian: No. 2 Memiliki penyimpanan khusus tetapi tidak tertata dengan baik. Catatan: kawasan daya tarik wisata Danau Beratan memiliki gudang khusus namun tidak terawat dan tertata dengan baik.

\section{Kesimpulan}

Penentuan nilai akhir mengacu pada pedoman Tri Hita Karana Awards. Dari hasil pemberian penilaian maka diperoleh hasil sebagai berikut: jumlah semua nilai yang diperoleh, total dari 1 sampai 18 mendapatkan penilaian 79 point.

Total $=\frac{79}{18} \times 20$

$$
=87,7
$$

adi disimpulkan bahwa kondisi keberadaan Danau Beratan tersebut tergolong very good.

\section{DAFTAR PUSTAKA}

Dalem, A.A.G.R. dkk.2007. Kearifan Lokal Dalam Pengelolaan Lingkungan Hidup.Denpasar:UPT Penerbit Universitas Udayana Bekerjasama Dengan Pusat Penelitian Lingkungan Hidup Unud.

Yasa,A.dan N.Yuhaeni.2000. Pelaksanaan dan Peran Tri Hita Karana dalam melaksanakan Pelestarian Lingkungan Hidup di Bali.Pp.421-446.Pro-siding Seminar Internasional "Konsep dan Implementasi Tri Hita Karana dalam Pembangunan Bali menyongsong Pelaksanaan Otonomi Daerah dalam Era Global", dilaksanakan oleh PUSAKA Bali di gedung Nari Graha Renon Denpasar tanggal 9 Agustus 2000.

Meganada,1990:58 dalam jurnal Perumahan dan Permukiman Tradisional Bali oleh Ngakan Ketut Acwin Dwijendra tahun 2003

Sulistyawati. Dkk, 1985:10 dalam jurnal Perumahan dan Permukiman Tradisional Bali oleh Ngakan Ketut Acwin Dwijendra tahun 2003 